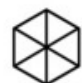 \\ LEUPHANA \\ UNIVERSITÄT LÜNEBURG
}

\section{Acquisitional pragmatics}

Barron, Anne ; Warga, Muriel

Published in:

Intercultural Pragmatics

DOI:

10.1515/IP.2007.008

Publication date:

2007

\section{Document Version}

Publisher's PDF, also known as Version of record

Link to publication

Citation for pulished version (APA):

Barron, A., \& Warga, M. (2007). Acquisitional pragmatics: Focus on foreign language learners. Intercultural Pragmatics, 4(2), 113-127. https://doi.org/10.1515/IP.2007.008

\section{General rights}

Copyright and moral rights for the publications made accessible in the public portal are retained by the authors and/or other copyright owners and it is a condition of accessing publications that users recognise and abide by the legal requirements associated with these rights.

- Users may download and print one copy of any publication from the public portal for the purpose of private study or research.

- You may not further distribute the material or use it for any profit-making activity or commercial gain

- You may freely distribute the URL identifying the publication in the public portal ?

If you believe that this document breaches copyright please contact us providing details, and we will remove access to the work immediately and investigate your claim. 


\section{Acquisitional pragmatics: \\ Focus on foreign language learners}

\section{Introduction}

Calls for research into the acquisition of pragmatic competence in a second language have been a familiar feature of the interlanguage pragmatic landscape since the 1990s. Indeed, one of the first of these many calls was made as early as 1992 by Kasper in an article focusing on pragmatic transfer. In this article, she writes "... the majority of interlanguage pragmatics studies focus on use, without much attempt to say or even imply anything about development" (1992: 204) (cf. also Kasper \& Dahl 1991). This observation was then verbalized rather forcefully in a very influential publication written by Kasper and Schmidt (1996) dedicated exclusively to the acquisition of second language (L2) pragmatic competence and designed "... to profile interlanguage pragmatics as an area of inquiry in second language acquisition research ..." (1996: 149). In this seminal publication, they write:

Interlanguage pragmatics, the study of the development and use of strategies for linguistic action by nonnative speakers, has a peculiar status in second language research. Unlike other areas of second language study, which are primarily concerned with acquisitional patterns of interlanguage knowledge over time, the great majority of studies in ILP has not been developmental. Rather, focus is given to the ways NNSs' pragmalinguistic and sociopragmatic knowledge differs from that of native speakers (NSs) and among learners with different linguistic and cultural backgrounds. To date, ILP has thus been primarily a study of second language use rather than second language learning. (1996: 150)

Such was the state of the art in the mid-1990s. Since the conception of this field in the early 1980s and up to the mid-1990s, interlanguage pragmatic (ILP) research had concentrated almost exclusively on learners' use of pragmatic knowledge. Research focusing on acquisition represented a research desideratum. It is, thus, little wonder that this call for research into the acquisition of L2 pragmatic competence has been reiterated repeatedly since this time in a range of noteworthy publications designed to advance the 
acquisitional side of ILP (cf., e.g., Bardovi-Harlig 1999; Kasper 2001; Kasper \& Rose 1999, 2002). Happily, these frequent calls have already begun to reap their rewards. Starting in the late 1990s, and particularly since the beginning of the present century, the number of empirical studies focusing on the acquisition of L2 pragmatic competence has begun to increase substantially (cf., e.g., Achiba 2003; Barron 2000, 2003; Churchill 2001; Code \& Anderson 2001; DuFon 1999, 2000; Félix-Brasdefer 2004; Hassall 2006; Hofmann-Hicks 1999; Matsumura 2001, 2003; Omar 2006; Otcu \& Zeyrek 2006; Pinto 2005; Rose 2000; Sabaté i Dalmau 2006; Salsbury \& Bardovi-Harlig 2000, 2001; Schauer 2004, 2006a, 2006b; Warga 2004). ${ }^{1}$ Despite these very encouraging developments, however, much remains unknown about the acquisition of L2 pragmatic competence, with many research questions still remaining open. Kasper and Schmidt (1996: 159), for instance, pose the question as to whether there is a natural route of development in the acquisition of $\mathrm{L} 2$ pragmatic patterns and also whether formulaic speech plays a role in such acquisition (1996: 163). While research since has pointed to the existence of possible developmental patterns and also to an important role for routine formulae in L2 pragmatic acquisition (cf. Kasper \& Rose 2002: 140; BardoviHarlig 2006: 6-20), this question can as yet not be answered conclusively. Also, it has been suggested that competence in particular speech acts may develop slower or faster relative to other speech acts due, for instance, to different levels of cognitive complexity possibly related in turn to differing degrees of conventionalization of the strategies involved. Refusals and complaints appear, for instance, to be among the speech acts which are slowest to develop, while requests are seen as among the fastest (cf. Barron 2003; House 1995, 1996; Trosborg 1995). However, further research is required before any conclusive statements can be made on this issue (cf. also Warga 2007). A further question which was raised by Kasper and Schmidt in this seminal article involves whether the type of input which learners are exposed to makes a difference in the acquisition of L2 pragmatic competence (1996: 159-160). This question has received particular focus in the area of study abroad acquisition (cf. Churchill \& DuFon 2006: 9-14 on the state of the art in this area) and in the study of the teachability and learnability of L2 pragmatic competence (cf. Rose 2005 for an overview of the state of the art here). However, here too, many questions remain unanswered and still in need of further exploration.

Apart from these open questions which remain, the focus of ILP empirical studies has been somewhat narrow. Many of the acquisitional studies have concentrated, for instance, on English as an L2 (cf. Barron 2003: 2934; Warga 2004: 61-63). Consequently, research focusing on languages other than English represents a particular research desideratum. In addi- 
tion, from a speech act perspective, requests continue to be the prototypical speech act in ILP acquisitional research (cf. also Barron 2003: 30-34; Warga 2005: 142). Consequently, research focusing on a wider range of pragmatic phenomena is also needed.

This special issue, entitled Acquisitional Pragmatics in Foreign Language Learning, is dedicated to further develop the field of acquisitional pragmatics by addressing many of these important questions and widening the data base. It comprises six empirical studies, all designed to meet the research gap for empirical acquisitional research in ILP. The collection of papers deals exclusively with the developing pragmatic competence of foreign language learners, both in the context of the foreign language classroom and during the study abroad experience, the latter which can be defined as a "... special case of second language acquisition ..." (Freed 1995: 4) in which "... learning remains instructed, despite incorporating elements of naturalistic L2 acquisition" (Coleman 1997: 4). All studies focus on acquisition in the absence of intervention. The target languages examined include English (Matsumura, Sabaté i Dalmau \& Curell i Gotor, Schauer), but also French (Warga \& Schölmberger), German (Barron) and Spanish (Félix-Brasdefer). The learners' first languages (L1s) also include a variety of languages, namely Catalan (Sabaté i Dalmau \& Curell i Gotor), English (American English: Félix-Brasdefer, Irish English: Barron), German (Austrian German: Warga \& Schölmberger, German German: Schauer) and Japanese (Matsumura). The speech acts investigated are apologies (Sabaté i Dalmau \& Curell i Gotor, Warga \& Schölmberger), offers of advice (Matsumura), refusals of offers (Barron) and requests (Félix-Brasdefer, Schauer).

The papers in this special issue focus on two central issues in the acquisition of foreign language pragmatic competence, namely on the effect of the study abroad context (Barron, Matsumura, Schauer, Warga \& Schölmberger) and on the effect of proficiency (Félix-Brasdefer, Sabaté i Dalmau \& Curell i Gotor) on the acquisition of L2 pragmatic competence. Given the short-term nature of the study abroad experience, it is not surprising that all four of the study abroad papers in this special issue are longitudinal in nature, tracing the development of the same participants throughout time. Both analyses of the effect of proficiency, on the other hand, are characterized by a cross-sectional design. In other words, they compare data from different groups of informants at one point in time, implicitly assuming that lower proficiency groups will "turn into" a higher proficiency group in time. This latter design feature allows the pragmatic competence of relatively large numbers of informants across a broad range of proficiency levels to be compared. The same study organized using a longitudinal design would take many years to conduct 
and would, for reasons of practicality, be forced to concentrate on a small number of informants. In addition, it is characteristic that all six empirical studies employ elicited data in their research design. These include a range of production questionnaires (Barron, Sabaté i Dalmau \& Curell i Gotor, Warga \& Schölmberger and Schauer [a multimedia elicitation task]), multiple choice questionnaires (Matsumura), interviews (Matsumura) and roleplays (Félix-Brasdefer). Such elicitation methods are ideally suited to large scale studies, such as those reported on in the present special issue, since they enable speech act realization data to be gathered from a large sample relatively quickly and easily. Furthermore, such instruments allow comparable data to be elicited from different groups of informants and also from one core group at different points in time, the latter design allowing informants' progress to be tracked through time (cf. Barron 2003: 84-85). Indeed, Cohen (2006: 361), in a recent article, highlights the practical difficulties which acquisitional studies face in their choice of data:

... in an interventional study like that by myself and Ishihara (2005) or the one we conducted with study abroad students (Cohen et al. 2005), it would have been close to impossible to collect pre- and post-instructional natural data, unless we had done an ethnographic study with a very small number of participants in each case.

In other words, while naturally-occurring data may be desirable, it is generally almost impossible to elicit, if comparability over larger groups of informants is also desirable. Needless to say, however, triangulation of data sources represents a practical alternative and one that should be attempted in future studies. Indeed, it might be suggested that such triangulation might take place not only on the level of data sources, but also as regards the approaches employed in ILP. In particular, the recent trend towards complementing the speech act focus in ILP with a conversational analytical approach in a so-called "discursive pragmatics" (cf. Kasper 2006: 282; cf. also Kasper 2004) represents one interesting possibility of widening the data base to include naturally-occurring data but also, importantly, of broadening the traditional speech act approach taken in ILP (cf. also Garces-Conejos Blitvich 2006: 214-215).

\section{L2 pragmatic acquisition in the study abroad context}

Papers by Barron, Schauer, Warga and Schölmberger and Matsumura in this special issue focus on the effect of the study abroad context on the acquisition of L2 pragmatic competence. Indeed, it is increasingly often 
that students, especially language students, spend an academic term or more in a foreign country as part of, or in addition to, their program of study in the home university. The traditional distinction between natural and educational contexts for the acquisition of a second language becomes blurred in the case of study abroad. On the one hand, study abroad includes two elements which differentiate it from acquisition in a natural context, namely a limited time-frame and an institutional framework (cf. Edmondson 2000: 365). In other words, after the study abroad period, learners return to the formal language learning context. In addition, the majority of students, whether foreign language students, or students of engineering or law, for example, will usually have acquired some prior knowledge of the target L2 via formal instruction in a language classroom in the home country, and will typically aim at increasing competence in the target language over time spent abroad. Furthermore, students usually attend language classes for learners in the target country. As a result, study abroad students, similar to learners who have been exposed to language in an educational setting only, view their target language for the most part as subject matter, i.e., as consisting of rules and principles which are to be attended to, rather than as a social entity (cf. also Barron 2003: 57-58). On the other hand, however, these study abroad students are exposed to the target language in its full social context during their year abroad, and the context of learning during this time is natural. As such, study abroad can neither be characterized as educational or natural. Instead it is seen as representing a unique case of second language acquisition (cf. Freed 1995: 4).

Study abroad research in linguistics remains rather narrow in focus, with the concentration continuing to be on elements of linguistic competence rather than on issues of use, despite the fact that a study abroad period represents one of the principal opportunities for learners to acquire such competence given a general disregard of such matters in the classroom setting (cf. Barron 2003: 66). As Kasper and Schmidt (1996: 159160) note:

Because pragmatic knowledge, by definition, is highly sensitive to social and cultural features of context, one would expect input that is richer in qualitative and quantitative terms to result in better learning outcomes. A second language environment is more likely to provide learners with the diverse and frequent input they need for pragmatic development than a foreign language learning context, especially if the instruction is precommunicative or noncommunicative.

It is not surprising that an extended, but limited, sojourn in the target speech community cannot lead to L2 pragmatic competence. Nevertheless, the general findings from study abroad investigations of the 
development of foreign language learners' L2 pragmatic competence reveal that exposure to second language input triggers some important developments. While many of these developments lead to an increasingly L2-like pragmatic competence, it has also been shown that some aspects of pragmatic competence do not change at all and also that not all changes recorded in learners' pragmatic competence over a sojourn abroad necessarily represent developments towards the L2 norm. In addition, in cases where movements toward the L2 norm are recorded, "toward" is indeed the appropriate word since it is rarely that the L2 norm is actually reached (cf. Barron 2003: 66-70; Kasper \& Rose 2002: 220230 for an overview of the individual findings of study abroad studies). Reasons which have been put forward for such differences in the development of different aspects of pragmatic competence include the quality, quantity and source of input to which learners are exposed, cultural and pragmatic stereotypes which may lead learners to reject the L2 norm in favor of their L1 norm, a lack of awareness of the pragmatic level of language and a basic assumption of the universality of pragmatic behavior and finally also the fact that some aspects of L2 pragmatics pose more or less difficulties for learners (cf. Barron 2003: 70-78; Kasper \& Rose 2002: 230-234).

The study abroad papers in the present volume (by Barron, Schauer, Warga \& Schölmberger, and Matsumura) add to the L2 pragmatic research in the study abroad context. All four studies elicited data from learners prior to, during, and also at the end of their sojourn abroad, with Matsumura also testing learners' competence up to one year after their return to the L1 speech community. In the following, the major changes observed in these analyses, when such changes occurred, their relative importance and their relation to the $\mathrm{L} 2$ norm are outlined. In addition, the studies shed further light on the complex interaction between L2-like developments, non-L2-like developments and a lack of development established in previous research and also investigate possible reasons for such developments. Development patterns are also traced, and indeed in this regard many of the issues discussed in the following section on the influence of proficiency on the acquisition of pragmatic competence are also of relevance.

Barron, in her paper entitled “ 'Ah no honestly we're okay:' Learning to upgrade in a study abroad context," focuses on the acquisition of upgrading in refusals of offers by 33 advanced Irish learners of German over a period of 10 months spent in a study abroad context. Her data, elicited using a free discourse completion task specifically designed to investigate discourse sequences, enabled an analysis beyond the usual level of the single utterance. Specifically, upgraders were analyzed as 
they occurred in both initial and subsequent refusals. Findings revealed learners' use of upgraders to be relatively high in both initial and subsequent refusals taken together prior to the sojourn abroad, but to be low in initial refusals alone relative to the L2 norm. Over time, however, learners' use of upgraders in initial refusals characterized by social distance or in the adjuncts employed therewith increased in an L2-like movement. This increase was shown to be due to a decrease in learners' negative transfer of ritual reoffers from Irish English into their interlanguage German, a development which meant that learners then felt a need to intensify the force of initial refusals produced. Interestingly, these higher levels of upgraders were found to be linked to the increased presence of formulaic utterances in refusals realized in interactions with strangers. Barron's study confirms the findings of previous studies which reveal negative transfer and the complexification hypothesis to have explanatory power in accounts of the acquisition of L2 modification and upgrading. In addition, it underlines the relative complexity of the speech act of refusals. However, the study also goes a step further in that it draws attention to the importance of analyses beyond the level of the single utterance and also in that it highlights the role of formulaic utterances in the acquisition of L2 upgrading.

Schauer's study investigates the use of external modifiers in requests produced by nine German university study abroad students over a period of one academic year spent in the L2 target speech community, England. Data were elicited at three distinct points during the learners' sojourn in the target language environment using a computer-based multimedia elicitation task (MET). Data elicited from 13 German learners of English in Germany with no study abroad experience serve as a control. Findings suggest that study abroad students have a broader repertoire of external request modifiers following a sojourn in the $\mathrm{L} 2$ context relative to foreign language learners who remain in the foreign language context. Schauer also notes, however, that individual learner differences, such as learners' experiences with native speakers, their exposure to the L2 and their motivation to establish personal relationships with NSs, may also play a role in learners' pragmatic development.

Warga and Schölmberger's paper, "The acquisition of French apologetic behavior in a study abroad context," investigates the effect of a ten-month stay in the target language community, Quebec, on the production of apologies by seven Austrian foreign language learners of French. Data were collected using a discourse completion task which was distributed prior to, during and following the year abroad. The analysis demonstrates that exposure to target language input caused some aspects of apologetic behavior to approximate the Quebecois French NS 
norm over the time spent in the target language community (e.g., decrease in the frequency of Excuses containing malheureusement ['unfortunately'] and of Justifications), some aspects to remain unaffected by the exposure (e.g., frequency of IFIDs) and other aspects to shift away from the L2 NS norm (e.g., increase of the use of two upgraders in one IFID/ RIFI, an increase in the use of très ['very'] and a parallel decrease in the use of vraiment ['really']). Pragmatic transfer from the L1 and also characteristic interlanguage behavior (e.g., overgeneralization) were identified as the explanatory factors for the lack of development of certain features and also for developments away from the L2 norm. Warga and Schölmberger's paper, thus, not only sheds light on the complex interplay of different paths of development, but also highlights the non-linear character of pragmatic development.

Finally, Matsumura's paper addresses an issue long disregarded in ILP research, namely the aftereffects of study abroad on the development of L2 pragmatic competence. Specifically, the study investigates the changes over time which emerged in the pragmatic competence of 15 foreign language university-level Japanese students of English in offering advice to individuals from three different levels of social status (i.e., higher, equal, and lower status) after they returned from an eight-month study abroad sojourn in Canada. Multiple choice questionnaire data revealed a gradual increase in the use of an opting-out strategy when giving advice to higherstatus persons after the year abroad, a development which peaked approximately one year after learners' return to the L1 context. This development signaled a divergence away from the Canadian English NS norm following learners' return to the L1 speech community. Qualitative data elicited using a retrospective group interview revealed that this divergence was partly the result of sociopragmatic transfer from the learners' L1 caused by personal circumstances which led to an increased awareness of the role of social status in Japanese society. However, the interview data also show that the students had actually become more competent in choosing an advice strategy in a context-sensitive manner over time. Specifically, they reported developing a strategy by which they began interactions by not giving advice and then adapted this linguistic choice where necessary, depending on contextual features. With regard to offering advice to individuals of equal or lower status, both the multiple choice and interview data demonstrated that the level of pragmatic competence in offering advice which the students had developed in the target speech community was maintained after they returned to their home country. Overall, the findings suggest that students may develop pragmatic competence even after their study abroad by fully utilizing opportunities to reflect on target socio-cultural norms. 


\section{The effect of proficiency on L2 pragmatic acquisition}

Papers by Félix-Brasdefer and Sabaté i Dalmau and Curell i Gotor in the present special issue are designed to further the investigation of the effect of proficiency on L2 productive pragmatic competence. Indeed, it is generally recognized in the ILP acquisitional literature that a learner's level of pragmatic competence is related to his/her level of proficiency. However, the exact nature of this link continues to remain unclear. Specifically, two major questions have been addressed in this area of research, namely on the one hand whether proficiency levels are related to higher or lower levels of pragmatic transfer and on the other hand whether learners' levels of grammatical competence constrain their L2 pragmatic competence. Both questions have, however, proved contentious and complex.

Turning first to the effect of L2 proficiency on transfer, there is evidence to suggest that an increase in linguistic proficiency may trigger an increase in pragmatic transfer, a trend which may be explained with reference to learners' increased linguistic competence (termed the positive correlation hypothesis as put forward by Takahashi \& Beebe 1987). However, other research findings indicate that an increase in linguistic proficiency may result in a decrease in pragmatic transfer (cf. Barron 2003: 47-48; Kasper \& Rose 2002: 153-157 for an overview of these contradictory findings). Indeed, linguistic proficiency may only be one factor influencing levels of transfer. Other factors include learners' opinions as to psycholinguistic markedness, i.e. as to whether a particular form or function is seen as unique to his/her L1, and indeed also learners' possible desire to employ L1 conventions in use of the L2. Further research is required into such complex interactions.

As to the question of the relationship between pragmatic competence and grammatical competence, two apparently contradictory positions are identified (cf. Kasper \& Rose 2002: 159-190). On the one hand, grammatical and pragmatic competence are seen as independent entities, i.e., although a lack of grammatical competence in a particular area may cause a particular utterance to be less effective, it does not necessarily represent a pragmalinguistic error, i.e. grammatical deviance can accompany L2-like speech act realizations (e.g. Schmidt 1983; Walters 1980; Olshtain \& Blum-Kulka 1985). On the other hand, research has also shown that a lack of grammatical competence can restrict a learner's capacity to produce linguistic action (cf., e.g., Salsbury \& Bardovi-Harlig 2000; Trosborg 1995). In other words, as Kasper and Rose (2002: 189) phrase it, evidence shows that "grammar precedes pragmatics." Indeed, Hassall (1997: 286-287) claims in this regard that the complexification hypothe- 
sis, put forward to explain developments in interlanguage grammatical competence, also has explanatory value in interlanguage pragmatics. Kasper and Rose (2002: 185-189, 190) appear, however, to solve this apparent contradiction in findings, concluding that the "pragmatics precedes grammar" order seems to characterize the early stages of pragmatic development, while the "grammar precedes pragmatics" order appears characteristic of advanced learners, i.e. learners have grammatical knowledge of a particular kind but do not use it in a pragmatically appropriate manner.

Finally, brief mention should be made of current research into patterns of acquisition established in ILP. As mentioned above, no order of acquisition has yet been established for pragmalinguistic or sociopragmatic elements, however, recent research findings do point to some patterns of development common to language learners (cf. Barron 2003: 48-55; Kasper \& Rose 2002: 117-158; Warga 2007: 188-189 for an overview of findings). Most work here has been done in the area of requests, and there appears to have emerged a particular order of acquisition of requests. In brief, it seems that direct request strategies give way to conventionally indirect strategies, and following this that the use of internal and external modification emerges - although there is debate as to whether internal or external modification develops first, and indeed, this particular order may be related to whether particular internal modifiers are used in the particular situation in the L1 (cf. Ellis 1992: 19; Hassall 1997: 251). Finally, sociopragmatic competence, on the other hand, appears to be slow to develop relative to pragmalinguistic competence particularly in the foreign language context. In addition, it may be particularly susceptible to resistance towards L2 practices in favor of L1 practices.

In the present volume, Félix-Brasdefer and Sabaté i Dalmau and Curell $i$ Gotor address such issues and so further the investigation of the effect of proficiency on L2 pragmatic competence. Both are cross-sectional designs and investigate the relationship of proficiency and L2 productive pragmatic competence over three levels of proficiency.

Félix-Brasdefer, in an article entitled "Pragmatic development in the Spanish as a FL classroom: A cross-sectional study of learner requests in face-to-face interaction", investigates the development of requests from the beginning of foreign language instruction to advanced levels of proficiency in face-to-face interactions. Data were collected using open role plays from three groups of 15 beginning, intermediate and advanced proficiency American learners of Spanish who had not received pragmatic instruction prior to data collection. Findings show beginners to produce the largest number of direct requests, thus showing little competence in situational variation. By contrast, intermediate and advanced learners 
revealed a strong preference for conventionally indirect requests in both formal and informal situations, with a decline in direct requests noted to appear with increasing proficiency. Such developments in the head act strategy, accompanied with further developments in internal and external modification, lead Félix-Brasdefer to conclude that sociopragmatic knowledge precedes grammatical competence in the performance of requests at least among his learners. Learners' grammatical competence is found to develop gradually and to adjust to learners' existing pragmatic competence. Finally, four developmental stages identified in the data for requests are discussed.

The final paper in this special issue is by Sabaté i Dalmau and Curell i Gotor. They report of a cross-sectional investigation focusing on the acquisitional stages of L2 apology realizations produced by 78 Catalan foreign language learners of English at three different proficiency levels. The analysis of the data, elicited by means of a discourse completion task, centers on the use and realizations of IFIDs by learners, the apology strategies employed and also on the degree and type of apology intensification used. All three proficiency groups were found to rely on their L1 pragmatic system to a certain extent and their interlanguage productions were characterized by interlanguage features, such as overgeneralization. On the other hand, however, higher proficiency learners were generally found to produce apologies which were pragmalinguistically more similar to L2 apologies than those produced by lower proficiency learners although this correlation was non-linear. Nevertheless, their apologies still evidenced non-L2-like features.

\section{Conclusion}

The repositioning of ILP from the study of second language pragmatic use to one which also encompasses the study of the acquisition of second language pragmatics is one which has been widely greeted. This special issue has been designed to continue and strengthen this promising trend by focusing on the acquisition of foreign language pragmatics and by including a wide variety of perspectives on FL pragmatics in a range of contexts and for a variety of learners. It is hoped that it will provide readers with novel and interesting perspectives on the acquisition of pragmatics in the context of study abroad and the foreign language classroom. 
Note

1. The studies listed here do not include studies designed to investigate the influence of classroom intervention on the development of L2 pragmatic competence. Cf. Alcón Soler and Martínez-Flor (2005), Martínez Flor et al. (2003) and Rose and Kasper (2001) for studies dealing with the effect of intervention in the foreign language context.

\section{References}

Achiba, Machiko. 2003. Learning to Request in a Second Language: Child Interlanguage Pragmatics. Clevedon, England: Multilingual Matters.

Alcón Soler, Eva and Alicia Martínez-Flor. (eds.). 2005. Pragmatics in Instructed Language Learning [Special issue]. System 33 (3).

Bardovi-Harlig, Kathleen. 1999. Exploring the interlanguage of interlanguage pragmatics: A research agenda for acquisitional pragmatics. Language Learning 49: 677-713.

- . 2006. On the role of formulas in the acquisition of L2 pragmatics. In: Pragmatics and Language Learning, vol. 11, Kathleen Bardovi-Harlig, J. César Félix-Brasdefer and Alwiya Omar (eds.), 1-28. National Foreign Language Resource Center, Honolulu: HI, University of Hawai'i Press.

Barron, Anne. 2000. Acquiring 'different strokes': A longitudinal study of the development of L2 pragmatic competence. German as a Foreign Language Journal (GFL Journal) 2, 1-29. Retrieved 3/8/2007 from the World Wide Web: http://www.gfl-journal.com/.

- 2003. Acquisition in Interlanguage Pragmatics. Learning How to do Things with Words in a Study Abroad Context. Amsterdam/Philadelphia: Benjamins.

Churchill, Eton. 2001. The effect of a study abroad program on request realizations by Japanese learners of English. Kanagawa University Studies in Language 24: 91-103.

Churchill, Eton and Margaret A. DuFon. 2006. Evolving threads in study abroad research. In: Language Learners in Study Abroad Contexts, Margaret A. DuFon and Eton Churchill (eds.), 1-30. Clevedon, England: Multilingual Matters.

Code, Simon and Aaron Anderson. 2001. Requests by young Japanese: A longitudinal study. The Language Teacher Online 25 (8). Retrieved 3/8/2007 from the World Wide Web: http://www.jalt-publications.org/tlt/articles/2001/08/anderson.

Cohen, Andrew D. 2006. Interlanguage pragmatics: A reply to Pilar Garces-Conejos Blitvich. Intercultural Pragmatics 3 (3): 359-364.

Cohen, Andrew D. and Noriko Ishihara. 2005. A web-based approach to strategic learning of speech acts. Report to the Center for Advanced Research on Language Acquisition (CARLA). Retrieved 2/1/2007 from the World Wide Web: http://www.carla.umn.edu/ speechacts/Speech_Act_project.pdf.

Cohen, Andrew D., R. Michael Paige, Rachel L. Shively, Holly A. Emert and Joseph G. Hoff. 2005. Maximizing study abroad through language and culture strategies: Research on students, study abroad program professionals, and language instructors. Final report to the International Research and Studies Program. Office of International Education, DOE. Minneapolis, MN: Center for Advanced Research on Language Acquisition (CARLA), University of Minnesota. Retrieved 2/1/2007 from the World Wide Web: http://www.carla.umn.edu/maxsa/documents/MAXSAResearchReport_000.pdf

Coleman, James A. 1997. Residence abroad within language study. State of the art article. Language Teaching 30 (1): 1-20. 
DuFon, Margaret A. 1999. The acquisition of linguistic politeness in Indonesian as a second language by sojourners in naturalistic interactions. Ph.D. diss., University of Hawai'i at Manoa.

-. 2000. The acquisition of negative responses to experience questions in Indonesian as a second language by sojourners in naturalistic interactions. In Social and Cognitive Factors in Second Language Acquisition. Selected Proceedings of the 1999 Second Language Research Forum ( $S L R F$ ), Bonnie Swierzbin, Frank Morris, Michael E. Anderson, Carol A. Klee and Elaine Tarone (eds.), 77-97. Somerville, MA: Cascadilla Press.

Edmondson, Willis. 2000. Grammatik und Kommunikation bei Auslandsaufenthalten. In Sprachlehrforschung im Wandel: Beiträge zur Erforschung des Lehrens und Lernens von Fremdsprachen. Festschrift für Karl-Richard Bausch zum 60. Geburtstag, Beate Helbig, Karin Kleppin and Frank G. Königs (eds.), 363-382. Tübingen: Stauffenburg.

Ellis, Rod. 1992. Learning to communicate in the classroom. A study of two language learners' requests. Studies in Second Language Acquisition 14 (1): 1-23.

Félix-Brasdefer, J. César. 2004. Interlanguage refusals: Linguistic politeness and length of residence in the target community. Language Learning 54 (4): 587-653.

Freed, Barbara F. 1995. Language learning and study abroad. In Second Language Acquisition in a Study Abroad Context, Barbara F. Freed (ed.), 3-33. Amsterdam/Philadelphia: Benjamins.

Garces-Conejos Blitvich, Pilar. 2006. Interlanguage pragmatics: A response to Andrew Cohen's 'Strategies for learning and performing L2 speech acts' published in vol. 2, No. 3, of Intercultural Pragmatics. Intercultural Pragmatics 3 (2): 213-223.

Hassall, Tim. 1997. Requests by Australian learners of Indonesian. Ph.D. diss., Australian National University.

- 2006. Learning to take leave in social conversations: A diary study. In Language Learners in Study Abroad Contexts, Margaret DuFon and Eton Churchill (eds.). 31-58. Clevedon: Multilingual Matters.

Hoffman-Hicks, Sheila D. 1999. The longitudinal development of French foreign language pragmatic competence: Evidence from study abroad participants. Ph.D. diss., Indiana University, Bloomington.

House, Juliane. 1995. Metapragmatische Bewußtheit, sprachliche Routinen und interkulturelles Lernen beim Wortschatzerwerb im Fremdsprachenunterricht. In Wortschatzerwerb und Wortschatzvermittlung, Karl-Richard Bausch, Herbert Christ, Frank G. Königs and Hans-Jürgen Krumm (eds.). 92-101. Tübingen: Narr.

-. 1996. Developing pragmatic fluency in English as a foreign language: Routines and metapragmatic awareness. Studies in Second Language Acquisition 18 (2): 225252.

Kasper, Gabriele. 1992. Pragmatic transfer. Second Language Research 8 (3): 203-231.

- 2001. Four perspectives on L2 pragmatic development. Applied Linguistics 22 (4): $502-530$.

-. 2004. Speech acts in (inter)action: Repeated questions. Intercultural Pragmatics 1 (1): $125-133$.

- 2006. Speech acts in interaction: Towards discursive pragmatics. In Pragmatics and Language Learning, vol. 11, Kathleen Bardovi-Harlig, J. César Félix-Brasdefer and Alwiya Omar (eds.). 281-314. National Foreign Language Resource Center. Honolulu: HI, University of Hawai'i Press.

Kasper, Gabriele and Merete Dahl. 1991. Research methods in interlanguage pragmatics. Studies in Second Language Acquisition 13 (2): 215-247.

Kasper, Gabriele and Kenneth R. Rose. 1999. Pragmatics and SLA. Annual Review of Applied Linguistics 19: 81-104. 


\section{6

—. 2002. Pragmatic Development in a Second Language. Malden, MA/Oxford: Blackwell.

Kasper, Gabriele and Richard Schmidt. 1996. Developmental issues in interlanguage pragmatics. Studies in Second Language Acquisition 18 (2): 149-169.

Martínez Flor, Alicia, Ester Usó Juan and Ana Belen Fernández Guerra (eds.). 2003. Pragmatic Competence and Foreign Language Teaching. Castellón, Spain: Servei de Publicacions de la Universitat Jaume I.

Matsumura, Shoichi. 2001. Learning the rules for offering advice: A quantitative approach to second-language socialization. Language Learning 51: 635-679.

-. 2003. Modelling the relationships among interlanguage pragmatic development, L2 proficiency, and exposure to L2. Applied Linguistics 24: 465-491.

Olshtain, Elite and Shoshana Blum-Kulka. 1985. Degree of approximation: Nonnative reactions to native speech act behaviour. In Input in Second Language Acquisition, Susan M. Gass and Carolyn G. Madden (eds.). 303-325. Rowley, MA: Newbury House.

Omar, Alwiya S. 2006. Kiswahili requests. Performance of native speakers and learners. In Pragmatics and Language Learning, vol. 11, Kathleen Bardovi-Harlig, J. César FélixBrasdefer and Alwiya Omar (eds.), 227-252. National Foreign Language Resource Center. Honolulu: HI, University of Hawai'i Press.

Otcu, Bahar and Deniz Zeyrek. 2006. Requesting in L2: Pragmatic development of Turkish learners of English. LAUD paper 680.

Pinto, Derrin. 2005. The acquisition of requests by second language learners of Spanish. Spanish in Context 2: 1-27.

Rose, Kenneth R. 2000. An exploratory cross-sectional study of interlanguage pragmatic development. Studies in Second Language Acquisition 22 (1): 27-67.

- 2005. On the effects of instruction in second language pragmatics. System 33 (3): 385399. [Special issue: Pragmatics in Instructed Language Learning, Eva Alcón Soler and Alicia Martínez-Flor (eds.)].

Rose, Kenneth and Gabriele Kasper. (eds.). 2001. Pragmatics in Language Teaching. Cambridge: Cambridge University Press.

Sabaté i Dalmau, Maria. 2006. From 'I am sorried' to 'I do apologise': Developmental stages in the acquisition of L2 apologies. LAUD paper 640.

Salsbury, Tom and Kathleen Bardovi-Harlig. 2000. Oppositional talk and the acquisition of modality in L2 English. In Social and Cognitive Factors in Second Language Acquisition. Selected Proceedings of the 1999 Second Language Research Forum (SLRF), Bonnie Swierzbin, Frank Morris, Michael E. Anderson, Carol A. Klee and Elaine Tarone (eds.). 57-76. Somerville, MA: Cascadilla Press.

—. 2001. 'I know you mean, but I don't think so:' Disagreements in L2 English. In Pragmatics and Language Learning (Monograph Series 10), Lawrence F. Bouton (ed.), 131151. Urbana, IL: University of Illinois at Urbana-Champaign, Division of English as an International Language.

Schauer, Gila A. 2004. May you speak louder maybe? Interlanguage pragmatic development in requests. In EUROSLA Yearbook, vol. 4, Susan H. Foster-Cohen, Michael Sharwood Smith, Antonella Sorace and Mitsuhiko Ota (eds.), 253-273. Amsterdam/Philadelphia: Benjamins.

-. 2006a. Knowing when to say what to whom: A longitudinal investigation of students' pragmatic development in a L2 university context. LAUD paper 648.

- 2006b. The development of ESL learners' pragmatic competence: A longitudinal investigation of awareness and production. In Pragmatics and Language Learning, vol. 11, Kathleen Bardovi-Harlig, J. César Félix-Brasdefer and Alwiya Omar (eds.), 135163. National Foreign Language Resource Center. Honolulu: HI, University of Hawai'i Press. 
Schmidt, Richard W. 1983. Interaction, acculturation, and the acquisition of communicative competence: A case study of an adult. In Sociolinguistics and Language Acquisition, Nessa Wolfson and Elliot Judd (eds.), 137-174. Rowley, MA: Newbury House.

Takahashi, Tomoko and Leslie M. Beebe. 1987. The development of pragmatic competence by Japanese learners of English. Journal of the Japanese Association of Language Teachers (JALT Journal) 8 (2): 131-155.

Trosborg, Anna. 1995. Interlanguage Pragmatics. Requests, Complaints and Apologies. Berlin/NY: Mouton de Gruyter.

Walters, Joel. 1980. Grammar, meaning and sociocultural appropriateness in second language acquisition. Canadian Journal of Psychology 34: 337-345.

Warga, Muriel. 2004. Pragmatische Entwicklung in der Fremdsprache. Der Sprechakt „Aufforderung "im Französischen. Tübingen: Narr.

—. 2005. 'Est-ce que tu pourrais m'aider?' vs. 'Je voudrais te demander si tu pourrais m'aider.' Les requêtes en français natif et en interlangue. Vox Romanica 64: 141-159.

-. 2007. Interlanguage Pragmatics in L2 French. In French Applied Linguistics, Dalila Ayoun (ed.), 171-207. Amsterdam/Philadelphia: Benjamins. 
